\title{
PENGARUH DEFISIENSI FOLAT TERHADAP FERTILITAS INDUK DAN KUALITAS JANIN TIKUS
}

\author{
Moch. Istiadjid E.S. \\ Laboratorium Bedah Fakultas Kedokteran Unibraw / RSU dr. Saiful Anwar Malang
}

\begin{abstract}
This experimental study was performed to reveals the association of folic acid deficiency with the rat's fertility and also with life quality of baby's rat. The level of folic acid deficiency were divided into two groups, consisted of severe and mild, based on the intake of folic acid, those were given to each groups that consist of ten mature Sprague-Dawley rats. Other were given normal folic acid as a control. Sixteen weeks after dietary suplly, rat's blood were evaluated to measure the contain of folic acid in the serum and erythrocyte and then the rats were forced mating. Baby rats were born with histerostomy. Rat's fertility were evaluated by measured the number of delivered baby's rat in 21th, 42th and 63th gestation or delivered days at each group. The quality of baby's rats were evaluated by measured the body weight of each baby and examined of any kind of congenital anomaly, such as spina bifida, encephalocele or anencephaly. The data analysis suggested the positive impact of maternal folic acid level in erythrocyte and maternal serum with the level of maternal fertility and life quality of the baby,s, especially its body weight. Thus, the deficiency of folic acid will cause maternal infertility, lowered body weight of the baby's rats and may be also congenital anomaly.
\end{abstract}

Key words: Folic acid deficiency, infertility, low body weight, congenital anomaly.

\section{PENDAHULUAN}

Asam folat adalah bagian dari vitamin B-komplek, terkait dengan asam pteroil-glutamat (Pte-Glu) yang bertindak sebagai ko-faktor enzim yang mentransfer satu unit karbon di dalam berbagai jalur metabolik (metabolic pathways). Metabolisme satukarbon yang dimediasi folat merupakan salah satu dari reaksi biokimia di dalam sel yang paling penting. Folat diperlukan untuk sintesis protein dalam asam nukleat dan mitokondria, serta metabolisme asam amino dan proses seluler lain yang melibatkan transfer satu unit-karbon. Folat dapat bertindak sebagai donor karbon atau dapat pula sebagai akseptor $(1,2)$.

Bentuk paling dominan dari folat yang beredar adalah 5methyltetrahyfolic acid (5-mTHF). Vit.B12 mengkonversi 5-mTHF menjadi tetrahidrofolat (THF), suatu bentuk metabolik-aktif folat lain yang diperlukan dalam berbagai proses biokimia penting. Senyawa ini muncul sewaktu biosintesis metionin yang dikatalisis oleh enzim metionin-sintetase dan ko-faktor metilkobalamin. Selama pembentukan metionin, enzim metionin-sintetase menggunakan $5 m T H F$ sebagai sumber gugus metil. Kurangnya produksi THF oleh sel mengakibatkan sel tersebut terhambat dalam mensintesis asam amino purin dan timin untuk replikasi DNA dan terhambat memetabolisme histidin dan serin $(1,3,4)$. Bentuk aktif asam folat adalah ko-enzim asam tetrahidrofolat dan enzim metilentetrahidrofolat-reduktase, yang dapat mentransfer gugus formil, hidroksi-metil, metilen dan forminin. Proses reaksi transfer itu berkaitan dengan biosintesis DNA, RNA, purin, metionin dan serin, serta katabolisme histidin $(5,6)$. Kekurangan ko-enzim tetrahidrofolat menyebabkan terhambatnya metilasi homosistein menjadi metionin, menimbulkan hiperhomosisteinemia $(3,7,8)$.

Defisiensi asam folat dapat menyebabkan masalah patobiologis karena gangguan dalam siklus metilasi enzimatik yang berakibat: hiperhomosisteinemia, perubahan genetik dan

Jurnal Kedokteran Brawijaya, Vol. XX, No.1, April 2004

Korespondensi: Moch. Istiadjid E.S; Lab. Bedah FK Unibraw; Jl. Veteran Malang-65145; telp (0341) 580993, 567192 fax. (0341)564755. atau gangguan sintesis protein $(1,4,9)$. Asam folat dengan bentuk aktifnya asam tetrahidrofolat memiliki tiga aksi metabolik: pertama, diperlukan untuk ko-enzim dalam konversi homosistein menjadi metionin; kedua, sebagai ko-faktor pada enzim yang mensintesis DNA dan $R N A$; dan ketiga untuk proses metilasi dalam pembentukan protein $(3,4,10)$.

Sewaktu awal pertumbuhan fetus, sintesis asam nukleat dan protein berada dalam kondisi puncak, dan selama masa itu kebutuhan folat maternal meningkat tajam. Bila folat tidak mencukupi, sintesis asam nukleat akan terhambat dan sel-sel tidak mampu memfasilitasi DNA untuk replikasi. Terhambatnya siklus metilasi mengakibatkan ketidakmampuan DNA untuk mensintesis protein, lipid dan mielin. Hal-hal tersebut kemungkinan dapat menyebabkan gangguan dalam fertilitas maternal dan proses embriogenesis pada janin $(11,12,13,14)$.

Istiadjid (2004) mendapatkan adanya korelasi positif antara defisiensi asam folat dengan kadar growth factor TGF- $\beta 1$ dan IGF-I dalam darah induk dan tulang kepala janin tikus. Juga ditemukan bahwa defisiensi asam folat menyebabkan jumlah selsel tulang kepala yang mengalami apoptosis dan nekrosis menjadi lebih banyak (15).

Defisiensi asam folat dapat disebabkan oleh asupan dalam diet yang rendah, malabsorpsi karena penyakit gastrointestinal, penggunaan yang tidak adekuat karena kurangnya enzim, pengobatan dengan antagonis folat, alkohol dan obat kontrasepsi oral, serta kebutuhan folat yang meningkat selama kehamilan dan beberapa kelainan proliferasi seluler. Rendahnya kadar asam folat dalam serum mencerminkan stadium pertama balans folat negatif yang 'mungkin' akan diikuti dengan turunnya kadar folat di jaringan. Rendahnya kadar asam folat dalam eritrosit mencerminkan stadium kedua balans folat negatif yang 'pasti' diikuti rendahnya kadar asam folat dalam jaringan (10).

Untuk mencegah tingginya risiko penyakit akibat defisiensi asam folat berupa cacat bawaan seperti NTD (Neural Tube Defects) dan CHD (Congenital Heart Disease), serta penyakit jantung koroner dan Alzheimer pada orang dewasa, Eskes et al. (1998), Oakley et al. (1996), Ray \& Laskin (1999) dan beberapa 
peneliti lain mengusulkan fortifikasi asam folat ke dalam tepung gandum, sehingga asupan asam folat tiap penduduk bertambah dengan paling tidak $400 \mu \mathrm{g} / \mathrm{hari}(7,14,16)$.

Penelitian ini bertujuan untuk mengungkap pengaruh defisiensi asam folat terhadap fertilitas induk tikus dan juga pengaruhnya terhadap kualitas janin yang dilahirkan, terutama berat badan janin dan ada tidaknya cacat bawaan.

\section{BAHAN DAN METODE}

Tigapuluh hewan coba tikus Sprague-Dawley usia 8 minggu dengan berat badan relatif sama, dibagi dalam tiga kelompok, masing-masing 10 ekor tikus. Kelompok-A diberi diet sangat rendah folat, Kelompok-B diberi diet rendah folat, dan Kelompok-C diberi diet folat normal. Pembuatan rangsum diet mengacu pada buku standar kandungan nutrien dan mikronutrien $(17,18)$, dengan komposisi sebagai berikut: glukose 350 gram, casein $100 \mathrm{gram}$, cellulose $70 \mathrm{gram}$, suksinilsulfatiazol $5 \mathrm{gram}$, choline 5 gram, sunflower oil $15 \mathrm{ml}$, mineral $2100 \mathrm{ml}$, trace element $20 \mathrm{ml}$, campuran vitamin (tanpa folat) $0.6 \mathrm{ml}$, dan asam folat (diberikan terpisah secara sonde oral) untuk Kelompok-A: 0.1 $\mathrm{ml}(=5 \mathrm{ug}), \mathrm{B}: 0,3 \mathrm{ml}$ (=15 ug), C: 0,6 $\mathrm{ml}(=30 \mathrm{ug})$.

Setelah 16 minggu, sampel darah diambil untuk pemeriksaan kadar asam folat eritrosit dan serum (dengan metode FIA, folate-imunoassay), TGF- $\beta 1$ serum serta IGF-I serum (metode Elisa, Enzyme-linked immunoabsorbent-assay). Tikus kemudian dikawinkan dan ditunggu bunting. Setelah usia kebuntingan 18-19 hari, janin-janin dikeluarkan secara histerotomi. Untuk mengetahui tingkat fertilitas induk, diamati kebuntingan yang terjadi di setiap tikus masing-masing kelompok pada setiap kelipatan 21 hari pasca kawin. Setelah terjadi kebuntingan, dari setiap induk secara acak diambil 2 ekor janin untuk ditimbang berat badannya dan diteliti kemungkinan adanya cacat bawaan secara makroskopis dari penampilan luarnya.

Data dianalisis dengan metode statistik Anova dan SEM (structural equation modeling).

\section{HASIL PENELITIAN}

Setelah dikawinkan, kebuntingan yang diharapkan tidak segera dapat terjadi. Seluruh tikus Kelompok-A baru dapat bunting setelah empat bulan, jauh lebih lama dibandingkan terjadinya kebuntingan pada tikus Kelompok-B dan $\mathrm{C}$ yang sudah dapat bunting seluruhnya dalam bulan kedua perkawinan. Di Kelompok-A tidak ada seekor tikus pun yang bunting dan atau melahirkan pada masa 21 hari pertama perkawinan, sementara pada masa yang sama terdapat 5 kelahiran pada Kelompok-B dan 6 kelahiran pada Kelompok-C. Tikus-tikus Kelompok-A baru dapat beranak setelah masa $5 \times 21$ hari, sedangkan pada Kelompok-B dan $C$ dalam masa $2 \times 21$ hari (duapuluh satu hari adalah masa kebuntingan induk tikus sampai kelahiran janin aterm).
Tabel 1. Kadar Asam Folat Dalam Eritrosit dan Serum Tiap Kelompok Induk Tikus.

\begin{tabular}{|c|c|c|c|c|c|c|}
\hline \multirow{2}{*}{ No. } & \multicolumn{2}{|c|}{ Kel.-A } & \multicolumn{2}{c|}{ Kel.-B } & \multicolumn{2}{c|}{ Kel.-C } \\
\cline { 2 - 7 } & E & S & E & S & E & S \\
\hline 1. & 741,2 & 7,4 & 867,2 & 14,3 & 905,2 & 15,2 \\
\hline 2. & 554,8 & 6,8 & ----- & 13,0 & ---- & 18,8 \\
\hline 3. & 549,6 & 8,8 & 816,4 & 13,1 & $1.311,3$ & 15,3 \\
\hline 4. & 665,0 & 5,2 & 923,0 & 15,3 & 824,0 & 14,8 \\
\hline 5. & 515,2 & 8,4 & 656,9 & 12,1 & 964,5 & 15,3 \\
\hline 6. & 629,1 & 5,7 & ---- & 12,4 & 656,3 & 15,0 \\
\hline 7. & 675,8 & 8,4 & ---- & 14,4 & ---- & 15,1 \\
\hline 8. & ------ & 3,1 & 878,8 & 14,7 & $1.202,4$ & 15,3 \\
\hline 9. & 616,2 & 5,8 & $1.176,7$ & 11,1 & 954,0 & 15,6 \\
\hline 10. & 742,5 & 3,8 & 778,1 & 14,4 & 880,0 & 16,0 \\
\hline \multirow{2}{*}{ Rerata } & 632,1 & 6,34 & 871,0 & 13,48 & 962,2 & 15,64 \\
\cline { 2 - 7 } & $\pm 65,8$ & $\pm 1,62$ & $\pm 04,4$ & $\pm 1,14$ & $\pm 147,9$ & $\pm 0,7$ \\
\hline p-value & \multicolumn{7}{|c|}{$0,001 / 0,000$} & \\
\hline
\end{tabular}

$$
\begin{aligned}
\text { Keterangan : } & E=\text { Eritrosit } \\
& S=\text { Serum } \\
& -----=\text { Sample rusak (lisis, beku) } \\
& - \text { Satuan yang dipakai : } \mathrm{ng} / \mathrm{ml} .
\end{aligned}
$$

Tabel 2. Berat Badan Janin Tikus (Gram)

\begin{tabular}{|c|c|c|c|c|}
\hline No. & Kel.-A & Kel.-B & Kel.-C & $p$-value \\
\hline 1 & $3,5 \pm 1,2$ & $3,9 \pm 2,1$ & $7,7 \pm 2,6^{*}$ & \\
\hline 2 & $4,4 \pm 1,4^{*}$ & $4,0 \pm 1,5$ & $7,3 \pm 1,2$ & \\
\hline 3 & $3,7 \pm 2,0$ & $3,8 \pm 1,6$ & $7,6 \pm 1,7$ & \\
\hline 4 & $3,6 \pm 1,1$ & $4,2 \pm 2,3$ & $7,7 \pm 1,5$ & \\
\hline 5 & $3,9 \pm 1,4$ & $4,6 \pm 2,1$ & $7,4 \pm 2,1$ & \\
\hline 6 & $3,6 \pm 1,9$ & $4,1 \pm 0,9$ & $7,5 \pm 2,4^{*}$ & \\
\hline 7 & $3,4 \pm 2,5$ & $5,3 \pm 1,1^{*}$ & $6,7 \pm 2,2$ & \\
\hline 8 & $4,2 \pm 1,7^{*}$ & $4,8 \pm 1,5^{*}$ & $7,1 \pm 1,8$ & \\
\hline 9 & $3,6 \pm 0,9$ & $5,1 \pm 2,0^{*}$ & $7,8 \pm 2,7^{*}$ & \\
\hline 10 & $4,1 \pm 1,8^{*}$ & $3,9 \pm 1,6$ & $6,8 \pm 1,9$ & \\
\hline Rerata & $3,8 \pm 1,6$ & $4,4 \pm 1,7$ & $7,4 \pm 2,0$ & 0,000 \\
\hline
\end{tabular}

Dalam Tabel-2 ditunjukkan berat badan janin Kelompok-A secara sangat bermakna lebih ringan dibandingkan Kelompok-B dan Kelompok-C (uji Anova, p= 0,000). Data tersebut diperkuat dengan penampilan janin dari masing-masing kelompok, seperti disajikan dalam Gambar-1, yaitu janin tikus Kelompok-A lebih kecil dibanding janin tikus dua kelompok lain. Didapat pula tujuh ekor janin Kelompok-A yang ekornya tidak tumbuh, sedangkan pada kelompok lain seluruh janin dalam keadaan normal. Dari seluruh janin yang dilahirkan, tidak dapat ditemukan adanya cacat bawaan.

Terdapat korelasi yang bermakna (analisis SEM, $p=0,035$ ) antara tingkat defisiensi asam folat dengan derajat infertilitas induk tikus. Semakin berat defisiensi folat, maka semakin kecil kemungkinan tikus untuk bunting. Dari Tabel-1 dan Tabel-2 terlihat pula korelasi positif antara defisiensi folat dengan berat badan janin tikus (analisis SEM, $p=0,001$ ). Artinya, semakin berat defisiensi folat, semakin ringan berat badan janin.

Untuk mengamati perilaku induk tikus terhadap janinnya, tiap kelompok disisakan 3 ekor induk yang tidak dilakukan histerotomi sehingga saat janin lahir, induk masih hidup. Ternyata semua janin Kelompok-A dimakan habis oleh induknya pada hari pertama pasca-lahir sehingga tidak dapat dideteksi adanya 
meningokel atau cacat bawaan yang lain, sedangkan kebanyakan janin kelompok-B dan $\mathrm{C}$ tetap hidup dan tidak cacat.

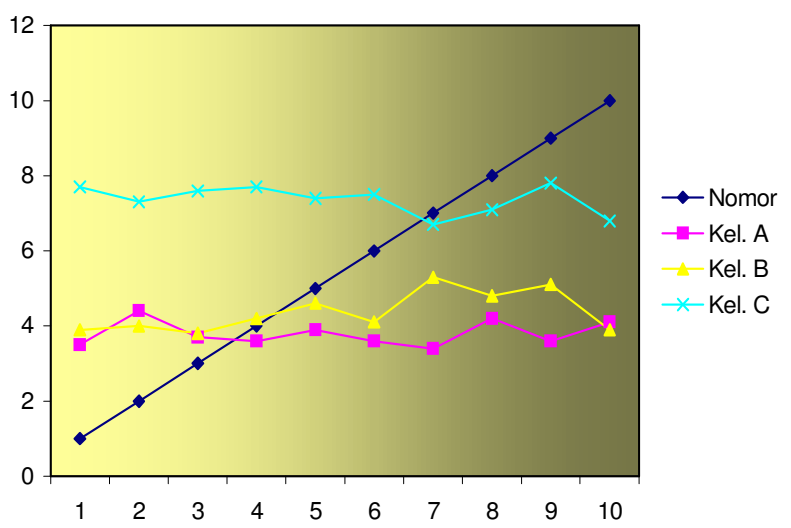

Grafik 1. Berat Badan Janin Tikus

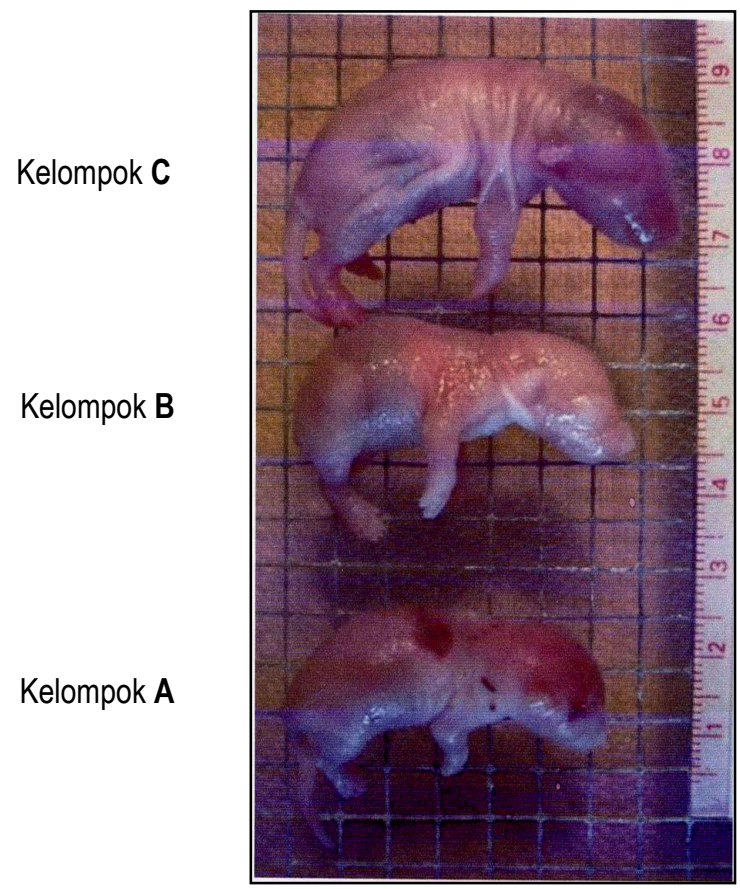

Gambar 1. Janin Tikus Tiap Kelompok

\section{PEMBAHASAN}

Selama proses penelitian, didapatkan fakta bahwa induk tikus Kelompok-A lebih sulit bunting dan beranak dibandingkan Kelompok-B dan Kelompok-C. Tidak ada seekor induk pun di Kelompok-A yang bunting dan beranak pada masa 21 hari pertama perkawinan, sementara pada masa yang sama terdapat 5 persalinan pada induk Kelompok-B dan 6 persalinan pada induk Kelompok-C (hampir semua janin dilahirkan dengan histerotomi).

Ada beberapa kemungkinan yang mendasari temuan tersebut. Pertama, akibat defisiensi asam folat maka tikus-tikus Kelompok-A menjadi subfertil sehingga sulit bunting. Kedua, sebenarnya sudah terjadi kebuntingan, tetapi karena kurangnya faktor yang mendukung proses embriogenesis dan implantasi, maka terjadilah abortus atau embrio diresorpsi oleh tubuh induk. Ketiga, telah terjadi persalinan preterm, tetapi setelah lahir semua janin langsung dimakan oleh induknya. Faktor pendukung proses embriogenesis secara teoritis berkaitan dengan defisiensi asam folat, yaitu kurangnya kadar faktor pertumbuhan TGF- $\beta 1$ dan IGFI yang juga beperanan dalam embriogenesis dan organogenesis, seperti yang diungkap oleh Gardner et al. (1999), Gross et al. (2001), Margawati (1999); O'Neil (1997) dan Scholl \& Johnson (2000) $(19,20,21,22)$.

Di samping itu didapat pula fakta bahwa berat badan janin Kelompok-A secara sangat bermakna lebih ringan dibandingkan Kelompok-B dan Kelompok-C ( $p=0,000)$ (Gambar 1 dan Tabel 2). Selain itu didapat pula tujuh ekor janin Kelompok-A yang ekornya tidak tumbuh, sedangkan pada kelompok lain, seluruh janin dalam keadaan normal. Temuan ini menunjukkan secara makroskopis adanya gangguan dalam proses tumbuh kembang pada janinjanin yang induknya diberikan rangsum rendah asam folat. Patut disayangkan dari seluruh janin tidak berhasil ditemukan adanya cacat kraniofasial, termasuk defek pada tulang kepala dan meningokel, kelainan yang merupakan pusat perhatian penelitian ini.

Margawati (1999) menyimpulkan bahwa keberadaan berbagai faktor pertumbuhan seperti LIF, EGF, IGF-I, TGF- $\beta$ dan $P A F$ diperlukan pada perkembangan embrio in vitro dan sebagai faktor pamicu bagi perkembangan zigot ke tahap preimplantasi embrio. Faktor pertumbuhan autokrin berperanan pada perkembangan embrio in vitro dan parakrin berhubungan dengan kondisi lingkungan mikro dari uterus untuk perkembangan embrio ke tahap preimplantasi. Pengimbuhan PAF, IGF-I, dan IGF-II pada media pembiakan embrio berkepadatan rendah dapat meningkatkan prosentase perolehan blastosist, sedangkan pengimbuhan EGF dan TGF atau kombinasinya pada biakan tunggal dapat meningkatkan perkembangan embrio ke tahap embrio pre-implantasi. IGF-I dan TGF- $\beta$ diketahui berpengaruh terhadap jumlah sel dari ICM dan trophectoderm pada embrio preimplantasi dan berat basah konsepsi (23).

Istiadjid (2004) melaporkan adanya korelasi positif antara defisiensi asam folat dengan kadar growth factor TGF- $\beta 1$ dan IGF-I dalam darah induk dan tulang kepala janin tikus. Juga ditemukan bahwa defisiensi asam folat menyebabkan jumlah selsel tulang kepala yang mengalami apoptosis dan nekrosis menjadi lebih banyak (15).

Terdapat hubungan antara kematian dini embrio (abortus) dengan cacat bawaan. Dari angka kelahiran hidup, 2.5-3\% janin menunjukkan adanya cacat bawaan, sedangkan pada kasus abortus, 90\% menunjukkan kelainan kongenital pada embrio. Jelas sekali bahwa embrio yang abnormal (cacat bawaan) sebagian besar akan mengalami kematian dini (abortus). Pada kasus abortus spontan, yang terjadi selama kebuntingan trimester pertama, sekitar $60 \%$ menunjukkan adanya kelainan kromosom, yaitu trisomi, monosomi atau triplodi. Embrio yang sedang tumbuh dan berkembang sensitif terhadap bahan toksik selama periode tertentu yang berkaitan dengan perkembangan sistem organ tertentu atau kelompok sel tertentu. Tahap kritis terjadinya kecacatan adalah selama periode organogenesis (proses pembentukan organ). Pada tikus, periode kritis tersebut adalah 
antara hari ke-6 sampai ke-15 masa kebuntingan yang 21 hari lamanya (24).

Pada manusia, asupan cukup folat harus tetap dipertahankan tidak hanya sampai sempurnanya penutupan neural tube (trimester pertama kehamilan) tetapi juga dalam fase kehamilan sesudahnya, dengan maksud untuk mengurangi risiko cacat bawaan lain. Masalah pokok dalam perkembangan embrio dan fetus adalah pemerataan pembelahan sel. Dalam masalah ini, asam folat mempunyai posisi sentral yang sangat penting karena peranannya dalam sintesis asam nukleat. Asupan asam folat yang rendah selama kehamilan akan mengganggu pertumbuhan dan replikasi sel dalam fetus atau plasenta. Selama kehamilan, rendahnya kadar asam folat dalam diet dan dalam sirkulasi darah berkaitan dengan tingginya risiko persalinan preterm, bayi yang ringan atau kecil dan retardasi pertumbuhan fetal. Salah satu efek metabolik dari defisiensi asam folat adalah hiperhomosisteinemia, yang dapat mengakibatkan abortus spontan dan komplikasi kehamilan lain, misalnya pelepasan dini (abruption) plasenta dan pre-eklamsia, yang akan meningkatkan risiko buruknya outcome kehamilan.

Karena keingintahuan peneliti untuk mengamati perilaku induk tikus terhadap janin-janinnya, setiap kelompok tikus disisakan 3 ekor induk yang tidak dilakukan histerotomi sehingga saat janin lahir, induk masih hidup. Dalam pengamatan, ternyata semua janin tikus Kelompok-A dimakan habis oleh induknya dalam sehari pasca-lahir meskipun kelihatannya tidak mengalami cacat, sedangkan kebanyakan janin tikus Kelompok-B dan C tetap hidup. Hume (1972) dan Arrington(1981) mengungkapkan fenomena bahwa induk tikus akan memakan anaknya yang lahir cacat. Dalam kaitan ini, berarti ada masalah dengan janin-janin tikus di Kelompok-A, meskipun tidak kelihatan cacat. Secara makroskopis, yang terlihat ada kelainan pada janin-janin tersebut adalah ukurannya yang lebih kecil dan berat badannya yang lebih ringan dibanding rerata berat janin dua kelompok lain; serta beberapa janin yang ekornya tidak tumbuh (7 ekor), sementara di dua kelompok lain semua janin lahir normal $(8,25)$.

Berat badan waktu lahir mudah dipengaruhi oleh faktorfaktor ekstrinsik, termasuk defisiensi nutrisi. Kelainan kongenital tertentu mempunyai hubungan dengan berat lahir yang rendah, sedangkan beberapa kelainan kongenital lainnya berhubungan dengan berat lahir yang tinggi $(23,24)$.

\section{KESIMPULAN}

Dapat disampaikan kesimpulan bahwa defisiensi asam folat dapat menyebabkan berat badan janin tikus lebih ringan dibanding yang normal. Semakin berat derajat defisiensi asam folat semakin kecil dan semakin ringan janin yang dilahirkan. Defisiensi asam folat dapat pula menyebabkan induk tikus menjadi sulit bunting (infertil), mungkin juga tikus sudah bunting tetapi mengalami abortus karena gangguan dalam tahap embrio preimplantasi, atau mengalami kelahiranan preterm. Dalam hal ini, dapat dikatakan bahwa defisiensi asam folat menyebabkan gangguan dalam embriogenesis janin tikus.

\section{DAFTAR KEPUSTAKAAN}

1. Brouwer DAJ, Welten HTM, Reijngoud DJ, Van Doormal JJ, Muskiet FAJ. Plasma Folic Acid Cutoff Value, Derived From Its Relationship with Homocyst(e)ine. Clin: Chemistry 1998; 44(7): 1545-1550.

2. Lehninger AL. Principles of Biochemistry. Worth Publ. Inc., Diterjemahkan oleh Maggy Thenawidjaja: Dasar-Dasar Biokimia, Jilid 1. Jakarta: Penerbit Erlangga; 1995.

3. Brouwer IA. Folic Acid, Folate and Homocysteine: Human Intervention Studies. Disertasi, Katholieke Universiteit Nijmegen. 1999.

4. Donosepoetro M. Folic Acid \& Homocysteine: The Essential Biochemistry, A Sypnosis. J Cardiovasc; Risk 1998; 5: 223-227.

5. Hol FA, et al. Molecular Genetic Analysis of The Gen Encoding The Trifunctional Enzyme MTHFD (methylenetetrahydrofolatedehydrogenase), methenyltetrahydrofolate-cyclohydrolase, formyltetrahydrofolate synthetase in Patients with Neural Tube Defects. Clin: Genet 1998; 53: 119-125.

6. Zittoun J, et al. Plasma Homocysteine Levels Related to Interactions between Folate Status and Methylenetetrahydrofolate Reductase: A Study in 52 Healthy Subyects. Metabolism 1998; 47(11): 1413-1418.

7. Eskes TK, et al. Neural Tube Defects, Vitamins and Homocysteine. Eur. J Pediatr 1998; 2: 139-141.

8. Hume CW. The UFAW Handbook on the Care and Management of Laboratory Animals. Edinburgh-London: Churchill Livingstone; 1972; 204-211.

9. Vohra M, Gentili A, Subir V, Chen D, Mosalem A, Siddiqi W. Folic Acid Defeciency. Medicine; 2002; 1-12.

10. Acuna J, Yoo P, Erickson D. The Prevention of Neural Tube Defects with Folic Acid. CDC, Pan Am. Health Org; 2000; 1-17.

11. Fleming A and Copp AJ. Embryonic Folate Metabolism and Mouse Neural Tube Defects. Science 1998; 280 (5372): 2107-2109.

12. Matinasevic MK, Rios GR, Miller MW, Tephly TR. Folate and Folate-Dependent Enzymes Associated with Rat CNS Development. Dev. Neurosci 1999; 21: 29-35.

13. Moeliandari F. Homosistein Sebagai Faktor Risiko Demensia dan Alzheimer. Informasi Laborat 2003; 5: 1-3.

14. Ray JG, Laskin CA. Folic Acid and Homocysteine Metabolic Defect and The Risk of Abruption, Pre-eclampsia, and Spontaneous Pregnancy Loss: A Systematic Review. J Plac Sep. 1999; $20(7):$ 519-529.

15. Istiadjid MES. Korelasi Defisiensi Asam Folat dengan Kadar TGF- $\beta 1$ dan IGF-I dalam Serum Induk dan Tulang Kepala Janin Tikus. Disertasi; Pasca-sarjana FK-Unair 2004.

16. Oakley GP, Adams MJ, and Dickinson CM. More Folic Acid for Everyone, Now. Am. Institute Nutr; 1996; 751S-755S.

17. Beck LS, Deguzman L, Lee WP, et al. TGF- $\beta 1$ Induces Bone Closure of Skull defects. J Bone Miner; Res 1991; 6: 1257.

18. Roth DA, Gold LI, Han VKM, McCarthy JG, Sung JJ, et al. Immunolocalization of Transforming Growth Factor $\beta 1, \beta 2$ and $\beta 3$ and Insulin-like Growth Factor-1 in Prematur Cranial Suture Fusion. Plast. Reconst. Surg 1997; 2(99): 300-309. 
19. Gardner RL, Squire S, Zaina S, Hills S and Ham CF. Insulin-like Growth Factor Regulation Conceptus Composition; Effect of The Trophectodrm and Inner Cell Mass Genotypes in The Mouse. Biol. Reprod 1999; 60: 190-195.

20. Gross SM, Caufiled LA, Kinsman SL, Ireys HT. Inaquate Folic Acid intake are Prevalent Among Young Woman with Nueral Tube Defects. J. Am; Diet Assoc 2001; 3: 342-345.

21. O'Neil C. Evidence for the Requirement of Autocrine Growth Factor for Development of Mouse Preimplantation Embryos in Vitro. Biology of Reproduction 1997; 56: 229-237.

22. Scholl TO and Johnson WG. Folic Acid: Influence on the Outcome of Pregnancy. Am. J. Clin. Nutr 2000; 71(supl): 1295S-1303S.

23. Margawati ET. The Effectivity of Growth Factor on in Vitro Embryo Development. Media Veteriner 1999; 6(3): 27-34.

24. Setokoesoemo BR. Masalah Pengaruh Lingkungan Pada Perkembangan Embrio. Pidato Pengukuhan sebagai Guru Besar FKUnair; Surabaya 1986

25. Arrington LR. Introductory Laboratory Animal Science: The Breeding, Care and Management of Experimental Animals. The Interstate Print. \& Publ. Inc. Illinois 1981; 59-88. 